\title{
Application of Postharvest Management of Corn to Support Integrated Farming System
}

\author{
Joko Nugroho Wahyu Karyadi*, Dwi Ayuni, Nursigit Bintoro, Sri Rahayoe, Bambang Purwantana \\ Department of Agricultural and Biosystems Engineering, Faculty of Agricultural Technology, Universitas \\ Gadjah Mada, Yogyakarta, Indonesia
}

Submitted: January $8^{\text {th }}$ 2020; Revised: June 11 ${ }^{\text {th }}$ 2021; Accepted: September $10^{\text {th }} 2021$

$\begin{array}{ll}\text { Keywords: } & \text { Abstiract Corn is a superior crop and its production centers are in the } \\ \text { Corn } & \text { Grobogan and Pati Regency, Central Java Province, Indonesia. This plant is } \\ \text { Cornsheller } & \text { partly cultivated in farm fields and forest land owned by Purwodadi Forest } \\ \text { Losses } & \text { Control Area (in Indonesiaknown as 'Kawasan Penguasaan Hutan - KPH) as an } \\ \text { Postharvest } & \text { intercrop during re-planting of tropical hardwood, namely teak. Corn has } \\ \text { technology } & \text { become one of the significant side hustles for most of the residents in KPH with } \\ & \text { high incomes. Unfortunately, this high corn production was not accompanied } \\ & \text { by adequate postharvest technology. Some vital problems occurred, especially } \\ & \text { during raining season, like fungi, undesired germination, and many more. } \\ & \text { Therefore, the weight loss of corn production is still very high. This activity } \\ & \text { aimed to assist farmers by changing how farmers look at the quality assurance } \\ & \text { of the produced corn products and improving farmers' postharvest corn } \\ & \text { practices. This activity's method was introducing corn harvesting machines, } \\ & \text { namely corn sheller machines, and improving the farmers' knowledgeabout the } \\ & \text { quality control of corn. The activities were carried out to allocate five (5) units } \\ & \text { of corn sheller units to five Forest Village Community Institutions (in Indonesia } \\ \text { known as 'Lembaga Masyarakat Desa Hutan,' LMDH) who were the targeted } & \text { partners. The activities of sharing the knowledge regarding good postharvest } \\ \text { for corn were going well and the participants gave excellent responses and } \\ \text { actively participated. }\end{array}$

\section{INTRODUCTION}

In Indonesia, Forest Village Community Organization (Lembaga MasyarakatDesa Hutan, LMDH) is a forum formed by the government to open forest village groups to be actively involved in forest management (Awang et a 1., 2008). In Central Java, LMDH was formed bythe Central Java Provincial Forestry Service Depa rtment and Perum Perhutani to group the community working on forestry land during replanting. This activity is carried out so that residents a round the forest can use the forest to increase their income. The LMDH group that formed was then guided to cultivate annual crops that could beplanted between teakwood, the staple crop in that area.

During their growth, teakwood requires plants intercropped with them. The role of these plants is crucial a s a protective ground surface, especially in the early rainy season. The plants under the teakwood can protect the soil surfa ce from ra inwater energy that falls directly or pass through the canopy oftrees and can be a source of soil organic matter. Root vegetation of the plants can grip the soil and stimulate soil aggregation, which reduces or prevents dispersion and erosion by surfacerunoff (Basuki \& Pra mono, 2017).

One of the annual crops that LMDH has been cultivating in Central Java is corn. According to the Indonesian Central Statistics Agency (BPS-Statistics Indonesia, 2019), in 2015, corn production in Indonesia rea ched more than 19.5 million tons, and the production figure in Central Java Province reaching more than 3 million tons. Grobogan Regency, Central Java, is known as one of Indonesia's national corn granaries (Ismail, 2019). Several groups in Grobogan and Pati Regency have corn as one of the production centers of

ISSN 2460-9447 (print), ISSN 2541-5883 (online)

${ }^{*}$ Corresponding author : Joko Nugroho Wahyu Karyadi

Department of Agricultural and Biosystems Engineering, Faculty of Agricultural Technology, Universitas Gadjah Mada J. Flora No. 1 Bulaksumur, Yogyakarta 55281, Indonesia

Email: jknugroho@ugm.ac.id 
their group. Unfortunately, general postharvest processes carried out in Indonesia are still not efficient. Based on the survey conducted by the Ministry of Agriculture of Indonesia (Direktorat Jen deral Tanaman Pangan, 2015), the losses of corn yields, especially in Central Java Province, were still relatively high, reaching $4.97 \%$. The losses details consisted of $1.69 \%$ in the harvesting stage, $0.28 \%$ in the corn shelling stage, and $2.99 \%$ in the drying stage.

The postharvest losses were usually caused by the traditional method or because of the im proper use of the machine. For the farmers in Grobogan and Pati Regency, the problem occurred from the lack of training for the farmers and postharvest technology that is difficult to access, especially during the rainy season. New technological innovations generally require additional costs; most farmers tend to a void risks while applying new technologies has consequences for the new risks (Sumarlan et al., 2012). This community service activity a imed to help LMDH in Grobogan and Pa ti regencies overcome corn harvest problems through activities including introducing corn sheller machines as postharvest technology and good postharvest practices for corn. After this activity, farmers were expected to maintain their corn quality from postharvest up to the selling process, so there could be welfare improvement in the end. The evaluation of the weaknesses and strengths of the activity was later discussed.

\section{METHOD}

All activities of this community service were carried out from August 2018 to November 2019. Several LMDH groups were chosen as partners in Grobogan and Patiregencies, and they a relisted in Table 1.

The groups in the village chosen each consisted of targeted farmers who would join the training on good corn postharvest practices. Figure 1 illustrates the flowchart of the activities in this community service. Firstly, the survey was done in each target village in Grobogan Regency and Pati Regency. The survey collected the data on the types of farming, general description of postharvest practices, and corn price at the farm level through interviews with the representative of each LMDH group. After the survey, the selection of corn sheller machines was carried out through the operation test to check their perfomance and fuel consumption. The choice of corn sheller was made based on the operation test and the input from the farmers.

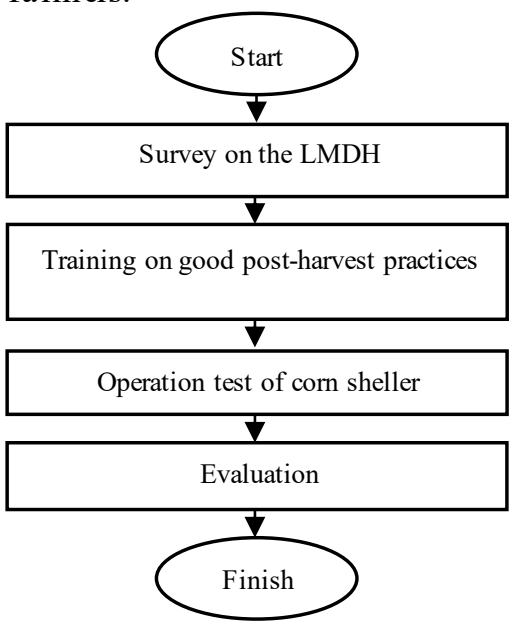

Figure 1. Research design in the flowchart

The training of good post-harvest practices by giving short seminars ended with a discussion session. The next activity was the demonstration of com shelling practice. In this activity, the farmers, accompanied by the team, practiced operating com sheller machines properly. Finally, evaluation and monitoring were carried out by visiting the LMDH groups periodically (onceevery 1-2 months) to monitor the use of corn shellers given, and whether the training has successfully given any improvement to the com postharvest practices. The monitoring and evaluation were done by interviewing representatives of the LMDH groups. Any difficulties or problems faced by the farmers were discussed and solved assisted by the community service team.

\section{RESULT AND DISCUSSION}

\subsection{Survey on the LMDH groups}

Firstly, the survey was done in Perum Perhutani to collect information about the potential of com production in both regencies. Perum Perhutani is a government-owned Enterprise in Indonesia that has the duty a nd a uthority to carry out planning, ma nagement, and forest protection in its working area. From Penum Perhutani KPH Purwodadi, it was obtained that the forest under KPH Purwodadi was about 19,000Ha. From that area, around $6,000 \mathrm{Ha}$ was allocated for farmers to plant corn as the intercrops during the replanting process. Based on this area's size, this proves

Table 1. LMDH groups in Grobogan and Pati Regencies

\begin{tabular}{|c|c|c|c|c|c|}
\hline \# & LMDH & Village & Subdistrict & Member & $\begin{array}{c}\text { Corn crops } \\
\text { Area (Ha) }\end{array}$ \\
\hline \multicolumn{6}{|c|}{ Grobogan Regency } \\
\hline 1 & Sidomulyo & Tegalsumur & Brati & 45 & 50 \\
\hline 2 & Jurang Jero & Penganten & Klambu & 270 & 172 \\
\hline 3 & Sidareja & Taruman & Klambu & 189 & 375 \\
\hline \multicolumn{6}{|c|}{ Pati Regency } \\
\hline 1 & Sidomakmur & Prawoto & Sukolilo & 491 & 650 \\
\hline 2 & Sumber Makmur & Pakem & Sukolilo & 381 & 550 \\
\hline
\end{tabular}

$211 \quad$ www.jurnal.ugm.ac.id/jpkm

Vol. 7, No. 3, Indonesian Journal of Community Engagement 
that corn has massive potential in Grobogan Regency and Pati Regency. The following surveys were carried out for each LMDH group and the location of com crops in the area (Figure 2).

From the results of a survey conducted, it was obtained that in one harvest, each farmer can harvest corn with a weight varying between 2.5-6 tons. However, some households can harvest up to 25 tons of corn. In general, the postharvest process of com was still carried out traditionally. Due to a lack of technology, training, and experience, farmers could not dry and store corn properly during the rainy season (February-March). As a result, farmers immediately sold their products to wholesalers or la rge tra ders, even at semi-dry conditions (moisture content of 30-35\%) for a round Rp2,700.00/kg only. Meanwhile, during the dry sea son (June-July), corn is a lrea dy in dry condition after harvesting, and this becomes an a dvantage for the farmers. They can store corn without being afraid of defection, and they can postpone their corn sale until the selling price becomes as high as they expect. Farmers can sell corn for a round Rp4,200.00/kg during the dry sea son.

Especially for the corn shelling process, the process wa s carried out in severalmethods, which were manual, semi-mechanical, and entirely mechanical. Ma nual shelling is done by removing kernels one by one from the cob, either by hand or with the help of simple tools. Corn shelling will not physically damage the kernels with this method even if the seedling moisture level is high ( $>30 \%$ ). This method is usually used for preparing corn as seeds. The disadvantage of this method is that it takes a long time and requires hard labor (Firmansyah et al., 2015). Semi-mechanical shelling involves using a corn sheller machine while the mechanical method involves the combined harvester machine.

Since corn crops of all the LMDH groups were grown in mountain a reas, the corn sheller machine was the best choice to shell corn effectively and faster than the manual method, and it is ea sy to be transported from one farmer's house to another. In every LMDH group, the corn shelling was usually done by renting a com sheller machine in each village at a cost of approximately Rp4,000.00 per $70 \mathrm{~kg}$ of corn. The capacity of the rented machine was 4 tons/hour. However, the limited number of corns sheller machines rented in each villa ge made the farmers had to queue to be able to rent and use it. As a result, the production losses might have been increased due to the fungi infection and undesired germination.

The main problems that can be formulated based on the situation analysis are comprised of postharvest technology knowledge that was still minimal, limited postharvest corn equipment, and that the LMDH groups were still unable to manage corn storage. Conceming these problems, the community service team agreed to carry out the activities described below.

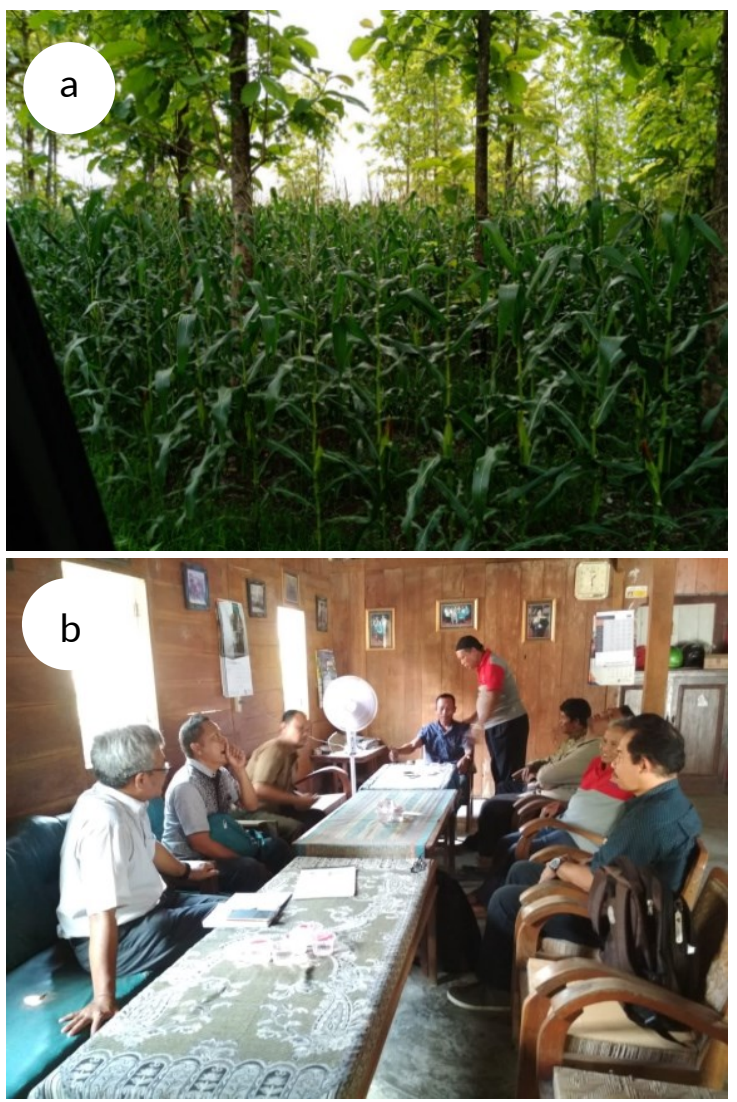

Source: Karyadi et al. (2019)

Figure 2. a) Survey on the corn crops area; b) Survey to the LMDH group

Allocating one corn sheller machine for each LMDH group. The semi-mechanic corn sheller machine was chosen as the most suitable type to be utilized by all LMDH. The performance test was done beforehand to know the capacity as well as the fuel consumption of the machine.

Conducting tra ining on good postharvest practice for corn to the LMDH groups. The training consisted of discussing the proper harvest time, corn shelling process, drying, sorting, and storage.

\subsection{Operation test of corn the sheller machine}

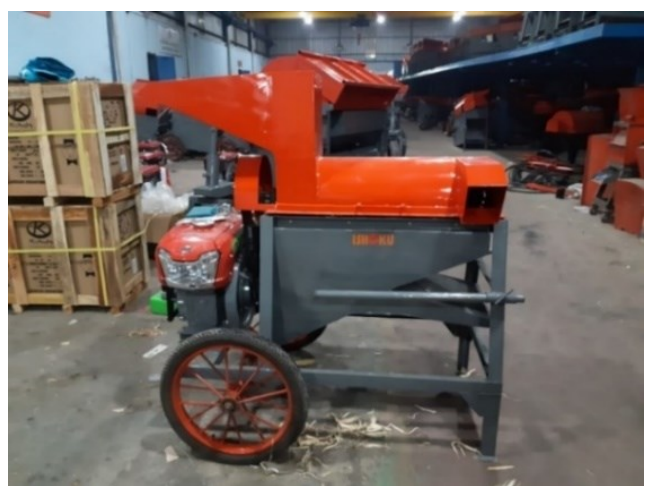

Source: Karyadi et al. (2019)

Figure 3. The selected corn sheller machine 


\begin{tabular}{|c|c|c|c|}
\hline No. & Performance tests & Units & Results \\
\hline 1. & $\begin{array}{l}\text { Feed rate capacity for corn } \\
\text { with husk }\end{array}$ & $\mathrm{kg} / \mathrm{h}$ & $\begin{array}{l}1,882.57 \pm \\
227.84\end{array}$ \\
\hline 2. & $\begin{array}{l}\text { Feed rate capacity for corn } \\
\text { without husk }\end{array}$ & $\mathrm{kg} / \mathrm{h}$ & $\begin{array}{c}2,491.44 \pm \\
303.04\end{array}$ \\
\hline 3. & $\begin{array}{l}\text { Shelling rate capacity for } \\
\text { corn with husk }\end{array}$ & $\mathrm{kg} / \mathrm{h}$ & $\begin{array}{c}1,232.91 \pm \\
125.98\end{array}$ \\
\hline 4. & $\begin{array}{l}\text { Shelling rate capacity for } \\
\text { corn without husk }\end{array}$ & $\mathrm{kg} / \mathrm{h}$ & $\begin{array}{c}1,895.31 \pm \\
190.76\end{array}$ \\
\hline 5. & $\begin{array}{l}\text { Fuel consumption for corn } \\
\text { with husk }\end{array}$ & $\mathrm{L} / \mathrm{h}$ & $0.70 \pm 0.17$ \\
\hline 6. & $\begin{array}{l}\text { Fuel consumption for corn } \\
\text { without husk }\end{array}$ & $\mathrm{L} / \mathrm{h}$ & $0.87 \pm 0.70$ \\
\hline
\end{tabular}

The next activity was to survey and select the proper corn sheller machine to be allocated. This activity was carried out to find a corn sheller machine that could suit the needs of the LMDH groups. Since the corn crops areas in Pati and Grobogan Regencies have similar topographic characteristics and corn yield production, the brand and capacity of the sheller ma chines that would be given to all the LMDH groups were similar. Finally, a corn sheller produced by CV Mandiri Garlica Pra tama CS 1200 GP was chosen and given to ea ch of the groups (Figure 3 ).

Table 1 shows the results of CS 1200 corn sheller performance testing done by the Testing Laboratory of Agricultural Machinery, Universitas Ga djahMada. The test results show that the corn shelling capacity was $1232.91 \pm 125.98 \mathrm{~kg} / \mathrm{h}$ for corn with husk and 1895.31 $\pm 190.76 \mathrm{~kg} / \mathrm{h}$ for corn without husk. The small size of the machine made it easy to be moved to other places as necessary. Themachinealso had a rela tively low fuel consumption, which was $0.70 \pm 0.17 \mathrm{~L} / \mathrm{h}$ diesel fuel for corn with husk and $0.87 \pm 0.70 \mathrm{~L} / \mathrm{h}$ for corn without husk. The other a dvantages were that the operation was relatively easy, and it only required two operators to opera te themachine.

\subsection{Training on good post-harvest practice for corn}

The next activity was training done in each village of Grobogan Regency and Pati Regency. The training was attended by 20 to $25 \mathrm{LMDH}$ members, and the materials were delivered by the community service team. During this training, farmers got curious about why their corn qua lity had decrease rapidly when the corn drying shelling process wa s not done quickly. For this question, the team explained the importance of the postharvest process of corn, and this process consisted of harvesting, shelling, drying, and packaging, and storage.

Corn harvesting must be done during the exact harvest time of the crops. Furthermore, this harvest time ca nnot be generalized since various corn seeds required different harvesting times. The next issue to be discussed was the excellent practice of corn shelling. The corn sheller machine can improve efficiency, reduce yield losses, and the quality of corn yields compared to traditional shelling practices (Kurniadi et a 1., 2015). However, the suitable type of corn sheller machine, the performance of the machine, and the condition of the material were crucial. The high moisture content of corncobs uploaded into the machine feeder could decrease the quality as the kemels with high moisture content were easier to break. According to the national standard of corn sheller machine (Badan Standarisasi Nasional, 2008), for optimal results, the corn shelling process must be preceded by the corncobs drying until their moisture content reaches $18-20 \%$.

In the storaging process, corn kernels are still undergoing a process of breathing and producing carbon dioxide, water vapor, and heat. If the conditions of the stora ge room are not controlled, there will be an increase in water concentration in the air around the storage area, thus providing ideal conditions for the growth of insects and fungus that destroy the com seeds. Another negative influence of the increase in temperature and the concentration of saturated air vapor is the increase of the respiration rate causing a side effect of increasing the a ir temperature in the storage room, which will accelerate the seed degradation process (Firmansyah et a 1., 2015). Overall, inadequate postharvest handling can cause a decrease in com quality due to the contamination of dangerous compounds, such as aflatoxin. Afla toxin compounds are secondary metabolites of Aspergillus fla vus, which can contaminate food. This contamination might be beca use of cancer in human body tissues, especially in the liver (Sukmawati et a 1., 2018). This tra ining a so explained the alternative processing method of com processing byproducts, which are cobs, steams, and dried leaves. Steams and cobs of corn are possibly be processed into cattle feed through a fermentation method. The remaining cobs can be processed into an energy source in the form of biomass pellets that can be used for the dry ing process and other purposes.

\subsection{Corn sheller machine operation practice}

After the farmers were given enough knowledge about the importance of good post-harvest practices, further a ssistance was carried out to demonstrate how to shell the corn using the machine (Figure 4). This assistance was conducted by the community service team and the employees of CV Mandiri Garlica. This activity consisted of doing practices and demonstrating the process of corn shelling. Some important information related to corn shelling practices was that it was pa ramount to ensure that the corn wa ter content wa s low (18-20\%) according to the Indonesian National Standard(SNI). In addition, during the shelling process, the rotation of the shelling cylinder must be kept constant at a speed of $600-800 \mathrm{rpm}$. 


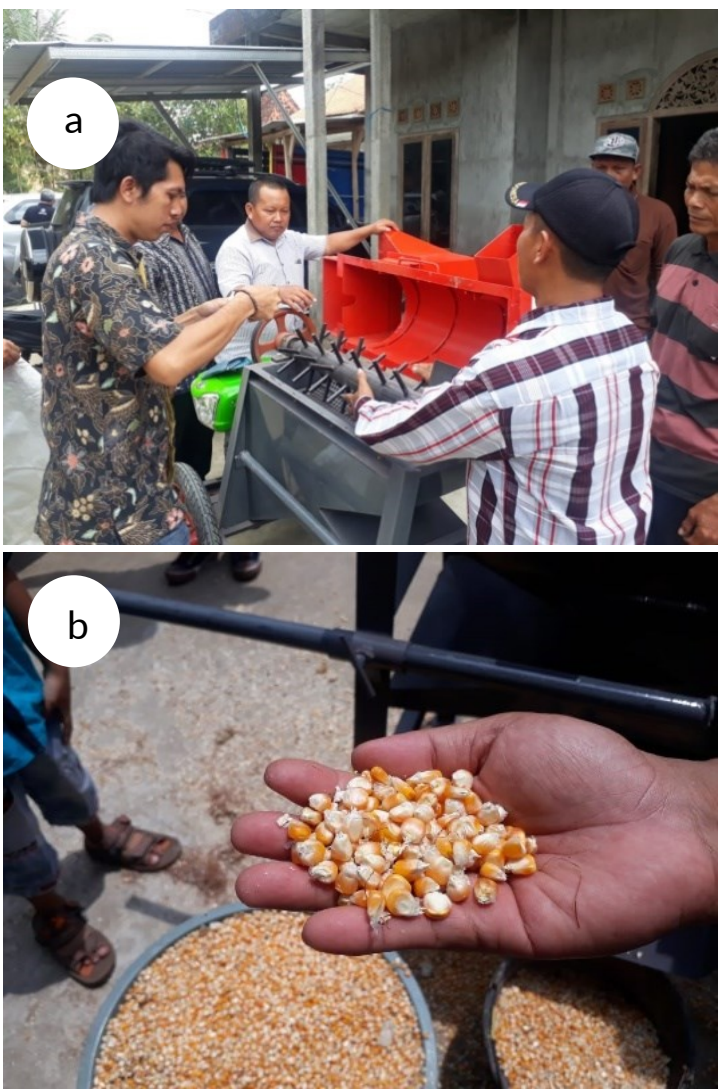

Source: Karyadi et al. (2019)

Figure 4. a) Corn sheller machine operation practice; b) Corn kernels produced

This constant speed rotation was essential to avoid damage to the corn a fter the shelling process that can be caused by the high moisture content or the exceedingly high cylinder speed. In addition to this demonstration, this a ctivity also provided explanations of how to maintain the corn sheller machines, including the oil change schedules, cleaning methods, and the suggestion of the proper condition to store the machine, so that it could last longer. Overall, by comparing the conditions before and after the community service activity, the evaluation results showed an increase in the farmers' knowledge and skills regarding the postharvest process for corn. The farmers showed high motivation and enthusiasm during the activities. The indicators of the program's success are shown in Table 3.

\subsection{Monitoring and evaluation}

From 2018 to 2019, this community service, whose aim was to apply post-harvest technology for corn, was carried out in $5 \mathrm{LMDH}$ groups in the target villages spread across Grobogan and Pati regencies. Monitoring and evaluation were conducted periodically to explore and assess the suitability of the technology and training through applications used by the targeted communities. From the evaluation results, in general, it wa s found that the corn sh eller machines allocated were suitable for the needs of these farmers mainly because most of them have had corn production with small yields ( $2-3$ tons/household). With the capacity of a lloca ted machines ( 2 tons $/ \mathrm{h}$ ), the corn shelling process could be done in one to two hours, so that in one day several members can do the shelling process a lternately. This result suggests that corn sheller use is more effective than having to wait for days in a queue to use a rented corn sheller machine. Eliminating the cost of renting the corn sheller also benefited the farmers.

On the other hand, the small capacity of the com sheller machine made it ineffective to be used by farmers who had large yields. Nevertheless, providing a corn sheller ma chine with a larger capacity was felt unnecessary because in essence this community service program aimed to help the communities to empower themselves in managing and using a shared corn sheller machine. If the allocated machine had a larger capacity, there was a concern that therewould be a monopoly on its use. In consequence, the assistance given by the community service team would have been ineffective. The a llocated machines would not be any different from the existing rented equipment before this community service program wa s carried out.

In terms of the ergonomics of their use, these machines were proven to be of good quality, easy to operate, and transportable. However, the small feeding table design was felt to hamper the feeding process. This problem triggered the active participation of the farmers to think of solutions. For example, in the LMDH in Sidareja in Ta ruman Village, the given com sheller machine was used routinely. The farmers there

\section{Table 3. Indicators of the program's success}

\begin{tabular}{|c|c|c|c|}
\hline No. & Criteria & Basic knowledge & After the activity \\
\hline 1. & $\begin{array}{l}\text { Farmers' knowledge about } \\
\text { post-harvest processes for } \\
\text { corn }\end{array}$ & $\begin{array}{l}\text { The Farmers only knew the post-harvest process } \\
\text { of corn in general. }\end{array}$ & $\begin{array}{l}\text { Participants understood the process of post-harvest } \\
\text { corn better, especially in the process of corn } \\
\text { shelling and storage. }\end{array}$ \\
\hline 2. & Training material provided & $\begin{array}{l}\text { There had never been any material delivered } \\
\text { about post-harvest technology for corn. }\end{array}$ & $\begin{array}{l}\text { The material presented was very relevant to the } \\
\text { issues faced by the farmers. }\end{array}$ \\
\hline 3. & $\begin{array}{l}\text { Interests and participations of } \\
\text { participants during activities }\end{array}$ & $\begin{array}{l}\text { 1. The corn shelling process was usually done } \\
\text { by using a rented corn sheller machine. } \\
\text { There had not been any training regarding } \\
\text { good practices of using corn sheller } \\
\text { machines. }\end{array}$ & $\begin{array}{l}\text { 1. Around } 80 \% \text { of all targeted farmers joined the } \\
\text { activity; it indicated that they had strong } \\
\text { enthusiasm to learn. } \\
\text { 2. During the activity, the participants actively } \\
\text { participated in the demonstration of the use of } \\
\text { the corn sheller machines. }\end{array}$ \\
\hline 4. & $\begin{array}{l}\text { The need for corn sheller } \\
\text { machines for the post-harvest } \\
\text { corn process }\end{array}$ & $\begin{array}{l}\text { The post-harvest process of corn had still been } \\
\text { carried out inefficiently. }\end{array}$ & $\begin{array}{l}\text { The corn sheller machines allocated suited to the } \\
\text { needs of the farmers and were proven to be } \\
\text { effective to improve corn harvest efficiency. }\end{array}$ \\
\hline
\end{tabular}


modified the feeding table so that it became longer, and the process of corn feeding into the sheller became ea sier. This exa mple is positive proof that the machine given to the farmers has been used routinely and effectively to help them in the corn shelling process.

\section{CONCLUSION}

The community service program focusing on the post-harvest technology for corn in Grobogan Regency and Pati Regency handed over five (5) units of com sheller ma chine to each of the targeted LMDH groups. In addition to giving a way these corn sheller machines, training activities were also carried out to help the farmers understand good post-harvest practices for better corn products. These activities increased the farmers' a wareness of good post-harvest practices and increased their participation in managing a gricultural machines. Machines given by the team to the farmers were proven to reduce the waiting time for the com shelling process; therefore, the loss from the shelling stage could be avoided, and corn quality could be maintained. Eliminating the cost of renting the com sheller a lso became a nother positive point. In the end, the target farmers confirmed the benefits from this community service program that it has increased their welfare.

\section{ACKNOWLEDGMENT}

This activity was funded by the Ministry of Research and Technology of Indonesia through a programnamed Penerapan Teknologi Tepat Guna of 2018 and 2019.

\section{REFERENCES}

Awang, S. A., Widayanti, W. T., Astuti, A., Septiana, R. M., \& Novenanto, A. S. (2008). Panduan Pemberdayaan Lembaga Masyarakat Desa Hutan (LMDH). Ja karta:Harapan Prima.

Badan Standarisasi Na sional. (2008). SNI 7428:2008 Mesin pemipilja gung - Unjuk kerja dan cara uji Retrieved July 24, 2020, from http://sispk.bsn.go.id/SNI/DetailSNI/7494

Basuki, T. M., \& Pramono, I. B. (2017). Hutan Jati. In UNS Press (Vol. 1). UNS PRESS. https://doi.org/10.1017/CBO9781107415324.00 4

BPS-Sta tistics Indonesia. (2019). Agriculture, Forestry, Livestock, and Fishery. In Sub-directorate of Statistical Compilation and Publication (Ed.), Statistical Yearbook of Indonesia (pp. 254-321). Jakarta: BPS-Statistics Indonesia.

Direktorat Jenderal Tanaman Pangan. (2015). Laporan Tahunan Direktorat Pascapanen Tanaman Pangan. Jakarta: Kementerian Pertanian Indonesia.

Firmansyah, I. U., Aqil, M., \& Sinuseng, Y. (2015). Penanganan Pascapanen Jagung. Maros: Balai Penelitian Tanaman Serelia.
Ismail, E. H. (2019). Ka bupaten Grobogan Siap Penuhi Kebutuhan Jagung Peternak. Retrieved July 1, 2020, from https://www.republika.co.id/berita/ekonomi/pert anian/19/01/31/ pm77ql453kabupatengroboga n-siap-penuhi-kebutuhan-jagungpeternak

Kurniadi, D., Abubakar, R., Dan, \& Afriyatna, S. (2015). Studi Komparatif Keuntungan Penggunaan Mesin Pemipil Jagung Kelobot Di Desa Banyu Urip Kecamatan Tanjhung Lago Kabupaten Banyuasin. Jurnal Societa, 67-73.

Sukmawati, D., Wahyudi, P., Rahayu, S., Moersilah, M., Handayani, T., Rustam, K. Y., \& Puspitasari, S. I. (2018). Krining Kapang Aspergillus Spp. Penghasil Aflatoksin pada Jagung Pipilan di Daerah Bekasi, Jawa Barat. Al-Kauniyah: Jurnal Biologi, 11(2), 151-162. https://doi.org/10.15408/kauniyah.v11i2.6961

Sumarlan, Sumardjo, Prabowo Tjitropranoto, D. S. G. (2012). Peningkatan Kinerja Petani Sekitar Hutan dalam Penerapan Sistem Agroforestri di Pegunungan Kendeng Pati. Agro Ekonomi, 30 No. 1(Mei), 25-39. 